\title{
Recent trends and status of women in Higher Education in India
}

\author{
Kapil M. Ingole*, Vicent Caballer**, Stephanie Galler*** \\ *MGM Institute of Health Sciences, India. \\ ${ }^{* *}$ Universitat Politècnica de València, Spain. \\ ****Birmingham City University, Creo, England
}

\begin{abstract}
The Indian education system is one of the oldest and largest in the world. Some progress has been made in the field of women's education. A recent trend shows that a huge number of female students are enrolling into higher education: $79.44 \%$ Undergraduate, $11.39 \%$ for Post graduate \& 0.72 $\%$ for Ph. D. The sex ratio in has increased; Gender Parity Index up to 0.88 in 2012 . Women's enrolment pattern has changed, currently it is much higher in Bachelor of Arts / Science / Commerce / Education than in non-technical / non-professional fields. A similar trend is being seen in Engineering Management and Technology in professional courses with less enrolment of women. This paper is an attempt to present the overall status of women in higher education.
\end{abstract}

Keywords: ASHE - Annual Status of Higher Education in States \& Union Territories, GER - Gross Enrolment Ratio, GPI - Gender Parity Index, MHRD - Ministry of Human Resource Development.

\section{Introduction}

\section{Historic background of Indian education System in India}

The Gurukul System of education was an ancient system of education during the Vedic period in which anyone who wished to study went to a teacher's Guru's home and requested to be taught. If accepted as a student by the Guru, the Guru taught everything the student wanted to learn, from Sanskrit to the Holy Scriptures, from Mathematics to Metaphysics (Kumar, 2014). During the Vedic period women had access to education in India, however, over time they lost this right to access education and academic exposure. The women had special customs, rituals and spirituality, with which men were not allowed to interfere. (Naik, 1978). This traditional system of education was in 1800 - 1900 replaced by the colonial system when the British ruled in India. After 1978 the colonial system was replaced by the National System of Education. The modern history of India, from 1857 to 1947, shows continuous efforts were made to educate the people enabling them to know their rights and duties towards their family, Society and Nation to enlarge and strengthen capabilities to fight ignorance, injustice, corruption, violence, disparity and communalism to fight for independence (Jitendra, April 2013) in the British period there was a revival of interest in women's education in India due to strong, British influence on the fundamentals of the Indian education system. During this period, various socio religious movements led by various social reformers in India who took various initiatives to make education available to the women (ASHE, www.aishe.gov.in, 2012). The women's right for education, which was lost after the Vedic period, was slowly recovered during this era. They were also ensured their participation in the social gatherings and events by introducing them into polity and administration at all levels during this period. (Naik, 1978) 
Women's education got a fillip after the country became independent in 1947, since then the government has taken various measures to provide education to all Indian women (Jitendra, April 2013). The Education Commission has stressed the need of women's education at all stages. To promote literacy in India, especially in rural areas and among the female population the government has done well in last decade as per Census 2011, 74.0\% of the population is literate comprising $65.5 \%$ females and $2.1 \%$ males. Among the States/Union Territories, the female literacy rate is the highest in Kerala at $92.0 \%$ the highest male literacy rate is observed in Lakshadweep at 96.1\%. (MHRD, 2013.) India with a population of more than 1.237 billion and $4.29 \%$ of GDP expenditure on education sector $79.44 \%$ under graduate. $11.39 \%$ for Post graduate and $0.72 \%$ for Ph.D.

The Radhakrishnan Commission (1948-49) in its reports has laid particular emphasis on women's education and has observed that Indian women can work like men in all spheres. Yet a large section of Indian society considers the home to be the only area for women's activities. Some people hold the view that unemployment will increase if women's education spreads. For the national development along with the women's education, the old values of society will have to be changed. It is also necessary to change the present system of women's education and make it more fruitful. In the past two decades, women's participation in primary, middle and secondary level has increased considerably. (IBEF, 2014) In the view of future perspective the education market in India, which is presently worth around Rs 5.9 trillion (US\$ 92.98 billion), is poised for some major growth in the years to come, as by 2020, India will have the world's largest tertiary-age population, and second largest graduate talent. Presently, higher education contributes 59.7 per cent of the market size, school education 38.1 per cent, pre-school segment 1.6 per cent, and technology and multi-media the remaining 0.6 per cent. The higher education sector in India is poised for an average growth of 18 per cent per year till 2020. (Pujar, Feb. 2014) The India's higher education system faces challenges on three fronts - expansion, equity and excellence (Jitendra, April 2013) which are well discussed in this paper. Indian education system ranks second in the world when comparing India, USA and China in terms of enrolment of students in higher educational institutions with Gross Enrolment Ratio GER 17.9\% in 2012 (Velkof, 1998).

In India lots of work is being carried out and most of the researchers have highlighted the various issues associated with education system and recommended various suggestions for improvement therein but very few attempts were made on women's status and their contribution in the Indian higher education system. The main objective of this study is to analyse the recent trends in higher education with pertaining to women's enrolment and their current status in higher education in India. 


\section{Methods}

This is a cross sectional, retrospective and descriptive type of research which is based on secondary data published in Research Articles, Journals, e-Journals, Report of state and central Governments as well as educational institutes. Various software such as Microsoft excel and word were used to represent and organise the data and with the statistical tools, techniques and graphical representation were use in order to organize, summarize the data for better understanding. The principle source of data are UGCs University Grant Commission report and ASHE - Annual Status of Higher Education in States and Union Territories -2012

\section{Results and Discussion}

Women's education in India has a major role in the social and economic development of the country. In recent years, India has progressed much in women's education to change the social face of country, despite there still being much to be done. The tremendous increase in the number of students and of the educational institutions has given rise to the term 'education explosion' in the country.

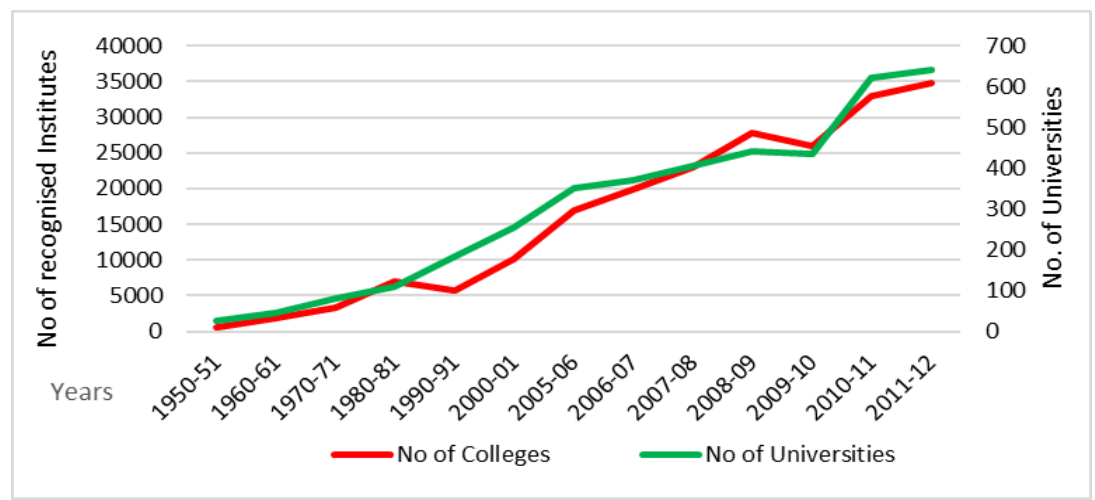

Figure 1 Number of Recognised Educational Institutions Data source: AISHE Portal (www.aishe.gov.in)

Fig1 shows the increase in recognised institutes and universities in India. With an increase in population the number of educational institutes, including colleges \& universities, have also increased, thus to fulfil the growing need for education which can be indicated by the overall enrolment.

There is no significant difference in the growth of enrolment rate between men and women in higher education since 1950. After 3 years of independence India had only 27 universities and 578 affiliated institutes, however, the population explosion has increased the demand of educational institutes which have increased, now numbering 254 universities and 10152 affiliated colleges by 2001. Currently there are 665 Universities, 35829 Graduate, PG, institutes with 29629022 students provides required knowledge, techniques, skills and information to $88 \%$ of students in regular mode. While $12 \%$ of the population is enrolled in a distance mode of education which includes one national \& thirteen state open universities which are providing the knowledge, techniques, skills required for continuation within their profession. 
The General courses (Arts, Commerce \& Education) account for 14.3 million and professional (Engineering, Medical, Management etc.) courses accounts for 7.1 million, general course having largest share of enrolment. Moreover, enrolment in professional courses has witnessed a higher growth in the last five years.

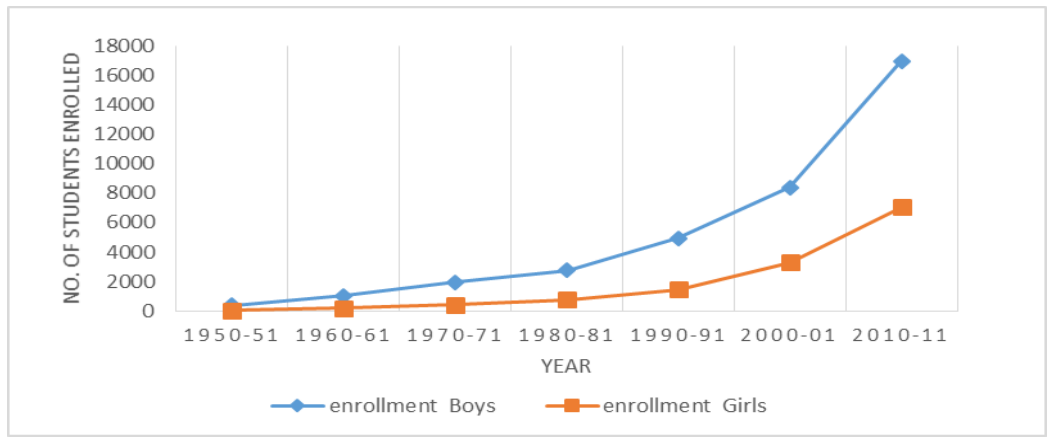

Figure 2: Growth of Students Enrolment ('000') in Higher Education Source: University Grant Commission report 2012

Fig 2 shows the total enrolment during 2012 among the various faculties, the maximum growth in enrolment being in the faculty of engineering (24.82\% increase), followed by commerce and management (5.46\%) and education (4.63\%). During 2011-12, the maximum enrolment of students have been in the faculty of arts (30.6\%), followed by engineering (24.3\%). Slightly above 3 percent of men and 1 percent of women attend college; women account for a third of the students at this level until 1993. This gender ratio is found in most fields of study, excluding firstly engineering and commerce, where women account for a much smaller proportion of the students; and secondly education, where women account for nearly half of all students

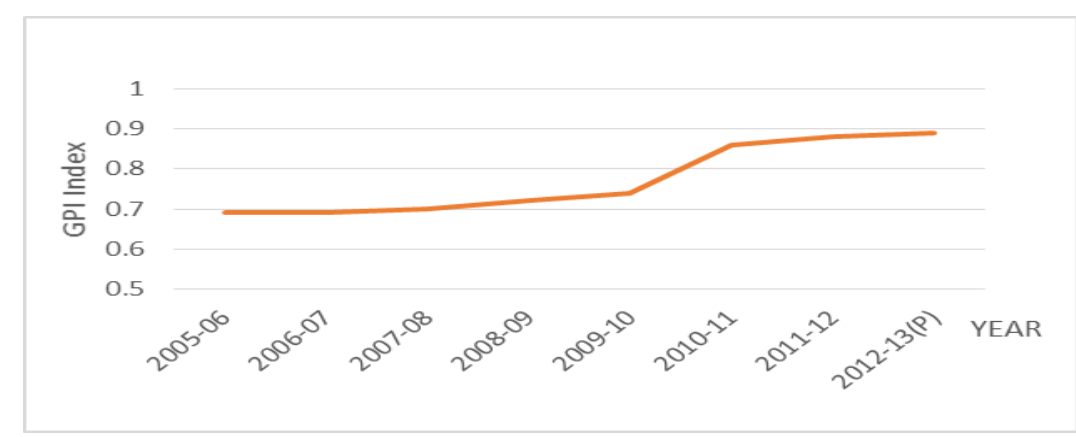

Figure 3: Gender Parity Index in Higher Education (18-23 Years) Source: MHRD Department of Education, Government of India

The Gender Parity Index (GPI) is a socioeconomic index usually designed to measure the relative access to education for males and females. In its simplest form, it is calculated as the quotient of the number of females by the number of males enrolled in a given stage of education. Gender equality has long been a major issue in Indian history since ancient times. Currently gender equality in education is one of the main 
priorities within every sector of Indian society, including education. The total number of girls enrolled per hundred boys was 13 in 1950, in 2012 this number increased to 81 resulting in an increase in the Gender Parity Index GPI of up to 0.89 in 2012 as shown in fig.3.

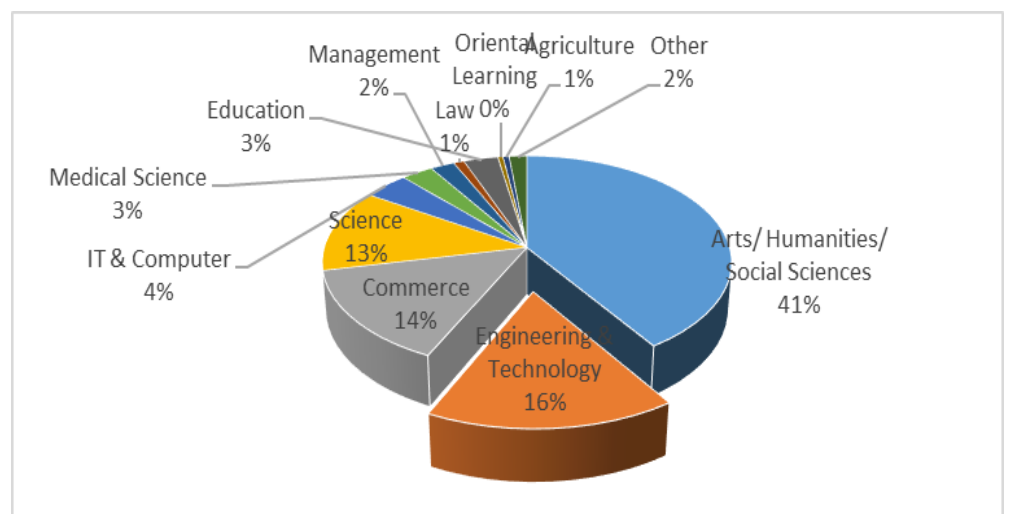

Figure 4 : Overall enrolment of students in different disciplines for UG programs.

Data source: AISHE Portal (www.aishe.gov.in)

Overall enrolment of students in different disciplines for UG programs. The Student enrolment is $79.44 \%$ undergraduate, amongst them $40.69 \%$ prefer to study Arts, Humanities and Social Science, 16 \% Engineering and Technology, 14 \% Commerce and 4\% IT \& Computer Science, while the most neglected fields of enrolment are Agriculture 0.55 and Law $0.95 \%$. At the master and Post Graduate level, only 11.39\% of enrolment for Post graduate and $0.72 \%$ for $\mathrm{Ph}$. D and additional research which are of similar enrolment numbers for both genders represented in fig.4.

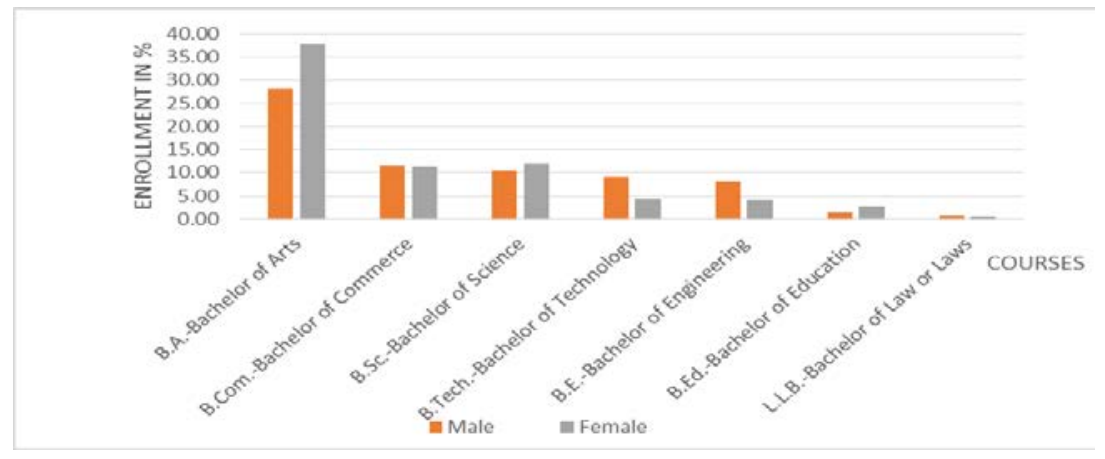

Figure 5 : Enrolment in different Programmes at graduation level (UG) Data source: AISHE Portal (www.aishe.gov.in)

At the graduation level certain programs, such as Bachlor of Arts and Bachlor of Science, women's enrolment is much higher than male's. Whereas in commerce \& MBBS. It's almost equal, notably in Bachlor of Engineering and Bachlor of Technology female enrolment is less when compared with male shown in Fig. 5 


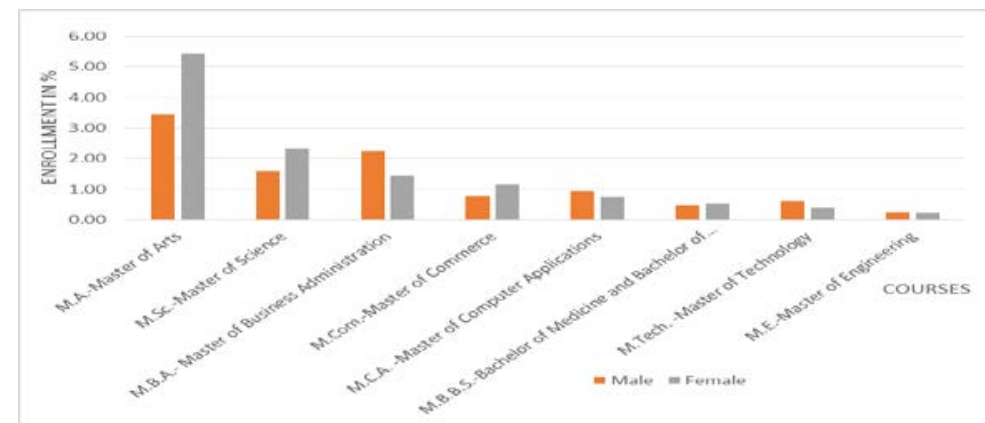

Figure 6: Enrolment in different Programmes at post graduate level

At the Post Graduate level there is a similar enrolment pattern being observed where in Master of Arts and Master of Science \& Master of Commerce women's enrolment is higher than men which is being almost equal at graduation level. Furthermore, a similar pattern is seen in Engineering, Technology and Management with fewer enrolment of women shown in Fig. 6.

In 2012 women's enrolment is higher in non-technical fields; According to MHRD in 1993 a very small percentage of the Indian population attends college, women account for a third of the students. This gender ratio is found in most fields of study excluding engineering and commerce, where female students are much fewer, and education, where nearly half are female students.

\section{Conclusions}

Indian education system is one of the largest in the world, having a network of more than 665 Universities, including one national \& thirteen state open universities. 35829 Graduate, PG, institutes in which general courses account for 14.3 million and professional courses accounts for 7.1 million; while more than 35 lakhs students enrolled in distance mode out of 2.96 million students in the country. Gender ratio in higher education has increased up to 80 girls per hundred boys resulting in an increase in GPI to 0.88 respectively. Over the last few years huge numbers of students are enrolling for higher education, a $1 / 4^{\text {th }}$ women and $2 / 3^{\text {rd }}$ male ratio was identified in the majority of the fields except engineering, where women's enrolment percentage was much lower. Women enrolled in education numbered almost half in comparison with men until 1992-93. However; at present women's enrolment is high in nonprofessional courses-Bachelor of Arts \& Science, almost equal in Bachelor of Commerce at graduation level, being higher at post-graduation Master of Commerce. Similar trends are being observed in Engineering Management and Technology as professional courses with fewer enrolments of women as compared with men resulted in different pattern.

In India very few efforts have been taken to explore the women's issues and status in higher education system further longitudinal researches are needed to explore for the improvement therein. 


\section{References}

ASHE. (2012). Annual Status of Higher Education in States and UTs, 2012. Retrieved from ASHE: http://www.aishe.gov.in

ASHE. (2012). http://www.aishe.gov.in Retrieved from ASHE.

Commission, U. G. ( Feb 2012 ). University Grant Commission (UGC) Report Feb 2012 . Delhi, India: University Grant Commission.

Commission, U. G. (2012). UGC Report .

Government of India, M. o. (2004). Selected Educational Statistics . Retrieved from http://mhrd.gov.in/highereducation

Gupta, N. (2003). Women's Education Through Ages,. New Delhi: Concept Publications Co.

IBEF. (2014, December ). Education Sector in India . Retrieved from India Brand Equity Foundation (IBEF): http://www.ibef.org/industry/education-sectorindia.aspx

India, G. o. (2011). Census report.

Jitendra, M. S. (April 2013). Status of Women Education in India. Educationia confab journal, 162 - 176.

Kumar. (2014, 12 7). The Education System in India. Retrieved from GNU Operating System: https://www.gnu.org/education/edu-system-india.html\#sasi

MHRD, G. o. ( 2013., October 26). Department of School Education and Literacy. Retrieved from "Sarva Shiksha Abhiyan".

Naik, j. P. (1978). Educational reform in India :a historical review. 1-2.

Pujar, U. (Feb. 2014). Trends in Growth of Higher Education in India . IOSR Journal of Economics and Finance, 01-04.

Velkoff, V. A. (October 1998). Women of the world. Womens Eduation in India. International Programs Center. 